University of Nebraska - Lincoln

DigitalCommons@University of Nebraska - Lincoln

2022

EMISSION OF VOLATILE ORGANIC COMPOUNDS FROM LANDAPPLIED BEEF CATTLE MANURE AS AFFECTED BY APPLICATION METHOD, DIET, AND SOIL WATER CONDITION

Bryan L. Woodbury

John E. Gilley

David B. Parker

David B. Marx

Follow this and additional works at: https://digitalcommons.unl.edu/biosysengfacpub

Part of the Bioresource and Agricultural Engineering Commons, Environmental Engineering Commons, and the Other Civil and Environmental Engineering Commons

This Article is brought to you for free and open access by the Biological Systems Engineering at DigitalCommons@University of Nebraska - Lincoln. It has been accepted for inclusion in Biological Systems Engineering: Papers and Publications by an authorized administrator of DigitalCommons@University of Nebraska Lincoln. 


\title{
EMISSION OF VOLATILE ORGANIC COMPOUNDS FROM LAND-APPLIED BEEF CATTLE MANURE AS AFFECTED BY APPLICATION METHOD, DIET, AND SOIL WATER CONDITION
}

\author{
Bryan L. Woodbury ${ }^{1}$, John E. Gilley,", David B. Parker ${ }^{3}$, David B. Marx ${ }^{4}$ \\ ${ }^{1}$ USDA-ARS U.S. Meat Animal Research Center, Clay Center, Nebraska, USA \\ ${ }^{2}$ USDA-ARS Agroecosystem Management Research, Lincoln, Nebraska, USA. \\ ${ }^{3}$ College of Engineering, West Texas A\&M University, Canyon, Texas, USA. \\ ${ }^{4}$ Department of Statistics, University of Nebraska, Lincoln, Nebraska, USA. \\ *Correspondence: john.gilley@usda.gov
}

\section{HighLIGHTS}

- The largest contributors to odor activity values (OAV) were heptanoic acid (23.5\%), hexanoic acid (17.6\%), indole $(14.7 \%)$, and dimethyl disulfide (DMDS) $(9.50 \%)$.

- Measurements of volatile organic compounds (VOC) were greater from plots where manure was surface-applied than from plots with incorporated manure.

- Emissions of DMDS and dimethyl trisulfide (DMTS) (0.318 and $0.074 \mu \mathrm{g} \mathrm{m}^{-2} \mathrm{~min}^{-1}$, respectively) were greater for plots with manure from beef cattle fed a diet containing 30\% wet distillers grains with solubles (WDGS).

- Rainfall immediately after manure application influenced the types and amounts of VOC that were emitted.

ABSTRACT. Land application of beef cattle manure may result in the emission of volatile organic compounds (VOC). This study was conducted to evaluate the effects of diet, land application method, soil water condition, and time since manure application on VOC emissions. Manure was collected from feedlot pens where cattle were fed diets containing $0 \%, 10 \%$, or $30 \%$ wet distillers grains with solubles (WDGS). The effects of manure application method (surface-applied or incorporated) and soil water condition (saturated or wet) on VOC emissions were measured over a 48 h period. Heptanoic, hexanoic, isobutyric, and isovaleric acids contributed 23.5\%, 17.6\%, 9.26\%, and 3.39\% (0.034, 0.258, 0.030, and $0.014 \mu \mathrm{g} \mathrm{m} \mathrm{m}^{-2}$ $\left.\mathrm{min}^{-1}\right)$, respectively, to total odor activity values $(\mathrm{OAV})$. The aromatics indole and skatole contributed $14.7 \%$ and $8.84 \%$, (0.005 and $\left.0.0004 \mu \mathrm{g} \mathrm{m} \mathrm{min}^{-1}\right)$, respectively, to total OAV. Dimethyl disulfide (DMDS) contributed 9.50\% (0.013 $\mu \mathrm{g} \mathrm{\textrm {m } ^ { - 2 }}$ $\left.\mathrm{min}^{-1}\right)$ and dimethyl trisulfide (DMTS) contributed 5.68\% (0.030 $\left.\mathrm{g} \mathrm{m} \mathrm{m}^{-2} \mathrm{~min}^{-1}\right)$ to total OAV. Emissions of the sulfur compounds (DMDS and DMTS) were substantially greater for the 30\% WDGS diet. With the exception of heptanoic acid, flux measurements were greater from the plots where manure was surface-applied than from the plots where manure was incorporated. Emissions of each VOC were greater on the first day following manure application when a saturated soil water condition was present. VOC flux values were found to rapidly decrease following manure application. Effective best management practices for reducing VOC emissions are to incorporate manure soon after application and to delay land application when there is a high probability of rainfall.

Keywords. Air contaminants, Air quality, Environmental management, Land application, Manure management, Odor control, Odor emission, Odor evaluation, Volatile organic compounds, Volatile fatty acids.

A irborne pollutants may be a concern to individuals living near animal feeding operations (AFOs) (Wright et al., 2005; Donham et al., 2007; Heederik et al., 2007; Katja et al., 2007; Thorne,

Submitted for review on 19 March 2021 as manuscript number NRES 14587; approved for publication as a Research Article by the Natural Resources \& Environmental Systems Community of ASABE on 8 December 2021

Mention of company or trade names is for description only and does not imply endorsement by the USDA. The USDA is an equal opportunity provider and employer.
2007). Much of the previous odor research on cattle AFOs has focused on odor characteristics and emission rates from feedlots (Auvermann et al., 2007; Kyoung et al., 2007; Todd et al., 2008; Trabue et al., 2008). Utilization of ethanol byproducts, including distillers grains, as a feed additive for beef cattle has influenced the characteristics of feedlot emissions (Gralapp et al., 2002; Varel et al., 2008, 2010; Spiehs and Varel, 2009).

Feeding wet distillers grains with solubles (WDGS) to cattle can increase both the intake and excretion of nitrogen, phosphorus, and sulfur. Feeding WDGS contributes to the 
production of odorous volatile organic compounds (VOC) such as long-chain and branched-chain volatile fatty acids (VFA) (Spiehs and Varel, 2009). VOC flux and odor activity values $(\mathrm{OAV})$ were found to be similar from feces and urine obtained from cattle fed steam-flaked corn diets containing varying amounts of WDGS (Hales et al., 2012; Spiehs et al., 2012 , 2018). The majority of the VOC emitted from cattle feeding operations is from urine deposition (Hales et al., 2015).

The frequency and duration of precipitation events on beef cattle feedlots cannot be altered. However, the rate at which the pen surface dries following a precipitation event can be modified. Feedlot management options that influence soil water condition and in turn odor emissions include (1) the amount of manure that is allowed to collect on the pen surface, (2) how well the drainage systems of the pens are maintained, and (3) the degree to which soil is mixed with manure on the pen surface (Woodbury et al., 2018).

Several areas associated with beef cattle AFOs may be a source of airborne pollutants, including feed storage areas, manure storage facilities, pen surfaces, and runoff holding ponds (Koelsch et al., 2004). Airborne pollutants from AFOs can include ammonia, bacteria, dust, endotoxins, hydrogen sulfide, particulate matter, and VOC (Mitloehner and Calvo, 2008). Malodorous VOC, including VFA, aromatics, and sulfides, are emitted during the microbial degradation of manure (Mackie et al., 1998; Miller and Varel, 2001; Miller and Berry, 2005; Rappert and Muller, 2005; Trabue et al., 2011).

The use of manure as a fertilizer and soil amendment can provide many soil quality benefits and contribute to improved agricultural sustainability (Tester, 1990; Fauci and Dick, 1994; Edmeades, 2003; Ferguson et al., 2005). However, airborne pollutants may also emanate from land on which cattle manure has been applied (McGinn et al., 2003). While VOC emissions from land-applied cattle manure originate from more diffuse sources than are typical for feedlot pen surfaces and manure storage facilities, land application areas may be closer to domestic housing areas than animal production facilities, creating a greater opportunity for odor concerns.

While there has been some research to evaluate the effects of land application of liquid dairy and swine manure on odor emissions (Hanna et al., 2000; Lau et al., 2003; Parker et al., 2013a; Liu et al., 2018), there has been limited research with beef cattle manure. Therefore, little information is available concerning best management practices for reducing VOC emissions following land application of solid manure. The objective of this study was to evaluate the effects of animal diet, land application method, soil water condition, and time since manure application on VOC emissions from areas on which beef cattle manure had been applied.

\section{MATERIALS AND MeTHODS STUDY SITE}

Field experiments were conducted during the summer of 2012 at the University of Nebraska Rogers Memorial Farm, located $18 \mathrm{~km}$ east of Lincoln, Nebraska. The site had been cropped using a grain sorghum (Sorghum bicolor (L.)
Table 1. Mean air temperature and humidity at the study site during the two sampling periods.

\begin{tabular}{ccc}
\hline Date & $\begin{array}{c}\text { Mean Temperature } \\
\left({ }^{\circ} \mathrm{C}\right)\end{array}$ & $\begin{array}{c}\text { Mean Humidity } \\
(\%)\end{array}$ \\
\hline 18 June 2012 & 30 & 59 \\
19 June 2012 & 29 & 60 \\
20 June 2012 & 22 & 79 \\
\hline 9 July 2012 & 27 & 55 \\
10 July 2012 & 23 & 58 \\
11 July 2013 & 22 & 62 \\
\hline
\end{tabular}

Moench), soybean (Glycine max (L.) Merr.), and winter wheat (Triticum aestivum L. cv. Pastiche) rotation, under a no-till management system, and was planted to winter wheat during the 2010-2011 cropping season. The area was left undisturbed following the wheat harvest in July 2011. Herbicide was applied as needed to control weed growth. Wheat residue was removed by hand raking prior to plot establishment.

The soil at the study site was classified as an Aksarben silt loam (fine, smectitic, mesic Typic Argiudoll). The soil contained $25 \%$ sand, $49 \%$ silt, and $26 \%$ clay and had a $\mathrm{pH}$ of 7.0 and organic matter content of $4.2 \%$. Mean air temperatures and average humidity during the study are shown in table 1.

\section{Beef Cattle Manure}

Beef cattle manure was collected from feedlot pens located at the U.S. Meat Animal Research Center near Clay Center, Nebraska. Calves born during the spring of 2011 were placed in the pens in October 2011. The cattle were fed a dry rolled corn-based diet that contained $0 \%, 10 \%$, or $30 \%$ WDGS. The animals were removed from the pens, and the surface was allowed to dry for several days. The manure was then collected from behind the feed bunk apron of the pens using a front-end loader. Under normal feedlot operating conditions, manure is usually stockpiled outdoors. However, in this study, the manure was stored indoors in $125 \mathrm{~L}$ plastic containers and allowed to air-dry until its weight no longer changed over time (approximately two weeks). A wood chipper was used to grind the manure until it passed through a $4 \mathrm{~mm}$ sieve, and then the ground manure was thoroughly mixed.

The manure was land-applied approximately 31 weeks (plots 501 to 506) or 34 weeks (plots 601 to 606) later on 18 June or 9 July 2012 (fig. 1). A composite consisting of ten grab samples was obtained prior to each land application date. The single composite sample obtained on each date was used to determine the physical and chemical characteristics of the manure including total nitrogen content (table 2) (Servi-Tech Laboratories, Hastings, Neb.).

\section{EXPERIMENTAL DESIGN}

Twelve plots $(0.75 \mathrm{~m} \times 2.0 \mathrm{~m})$ were established using a randomized block design (fig. 1). The experimental treatments included manure application method (surface-applied or incorporated immediately after manure application), diet $(0 \%, 10 \%$, or $30 \%$ WDGS), soil water condition (saturated or wet), and time since manure application: 0 (24), 1 (25), 2 (26), 6 (30), or 23 (47) h (sampling times for the wet soil water condition on day 2 are shown in parentheses). The 


\begin{tabular}{|c|c|c|c|c|c|}
\hline \begin{tabular}{|c|} 
Surface-applied \\
$30 \%$ WDGS \\
Plot 501 \\
\end{tabular} & $\begin{array}{c}\text { Disked } \\
0 \% \text { WDGS } \\
\text { Plot } 502 \\
\end{array}$ & \begin{tabular}{|c|} 
Surface-applied \\
0\% WDGS \\
Plot 503 \\
\end{tabular} & \begin{tabular}{|c|} 
Surface-applied \\
$10 \%$ WDGS \\
Plot 504 \\
\end{tabular} & $\begin{array}{c}\text { Disked } \\
30 \% \text { WDGS } \\
\text { Plot } 505 \\
\end{array}$ & $\begin{array}{c}\text { Disked } \\
10 \% \text { WDGS } \\
\text { Plot } 506 \\
\end{array}$ \\
\hline $\begin{array}{c}\text { Disked } \\
10 \% \text { WDGS } \\
\text { Plot } 601\end{array}$ & \begin{tabular}{|c|} 
Surface-applied \\
0\% WDGS \\
Plot 602 \\
\end{tabular} & \begin{tabular}{|c|} 
Surface-applied \\
$30 \%$ WDGS \\
Plot 603 \\
\end{tabular} & $\begin{array}{c}\text { Disked } \\
30 \% \text { WDGS } \\
\text { Plot } 604\end{array}$ & \begin{tabular}{|c|} 
Surface-applied \\
$10 \%$ WDGS \\
Plot 605
\end{tabular} & $\begin{array}{c}\text { Disked } \\
0 \% \text { WDGS } \\
\text { Plot } 606\end{array}$ \\
\hline
\end{tabular}

Figure 1. Schematic of plot layout, application method, and manure source. WDGS is wet distillers grains with solubles used in the diet. Plots 501 to 506 were contained in block 1, while plots 601 to 606 were contained in block 2 .

Table 2. Laboratory analyses of manure from beef cattle fed diets containing wet distillers grains with solubles (WDGS).

\begin{tabular}{cccc}
\hline & \multicolumn{3}{c}{ WDGS Content } \\
\cline { 2 - 4 } & $0 \%$ & $10 \%$ & $30 \%$ \\
\hline Total nitrogen (\%) & 1.36 & 1.75 & 1.94 \\
Organic nitrogen (\%) & 1.30 & 1.66 & 1.74 \\
Ammonium nitrogen (\%) & 0.028 & 0.045 & 0.190 \\
Nitrate nitrogen (\%) & 0.030 & 0.021 & 0.007 \\
Phosphorus (\%) & 0.359 & 0.415 & 0.857 \\
Water (\%) & 26.9 & 25.1 & 11.7 \\
Solids (\%) & 73.1 & 74.9 & 88.4 \\
Organic matter (\%) & 31.3 & 46.5 & 42.3 \\
Ash (\%) & 41.9 & 28.5 & 46.1 \\
C:N ratio & 13.4 & 15.4 & 12.7 \\
\hline
\end{tabular}

experimental plots were contained within $20 \mathrm{~cm}$ wide sheet metal frames driven approximately $10 \mathrm{~cm}$ into the soil. The sheet metal frames prevented runoff from outside the plot from entering the test area.

For quantification of background emissions without manure addition, another set of six plots was established immediately adjacent to the twelve plots identified previously. Three of the six plots had water applied until runoff was observed at the bottom of the plots, and three were left in a dry condition. A hand-operated irrigation wand was used to apply water to the plot surfaces. Wind tunnels were installed, and background emissions were collected using the experimental procedures described below. Background values for each of the measured compounds are listed in table 3 .
Flux measurements were taken on 18 to 20 June 2012 for plots 501 to 506 ( 1 to 2 days after the first manure application) and on 9 to 11 July 2012 (1 to 2 days after the second manure application) on plots 601 to 606 (fig. 1). There were six sets of sampling equipment, and flux samples were collected simultaneously from the six plots within each experimental block. Adjustments for differences in solar radiation, air temperature, turbulence, and other climatic conditions among sampling days were not made, but the ambient temperature was recorded (table 1).

Solid beef cattle manure was applied to meet the oneyear $\mathrm{N}$ requirement for corn $\left(151 \mathrm{~kg} \mathrm{~N} \mathrm{ha}^{-1}\right.$ year $^{-1}$ for an expected grain yield of $9.4 \mathrm{Mg} \mathrm{ha}^{-1}$ ). Based on laboratory analysis of the manure, application rates for each plot were calculated assuming that the first-year $\mathrm{N}$ availability from the manure was $40 \%$ (Eghball et al., 2002). Manure was uniformly applied by hand across the plot surfaces using $19 \mathrm{~L}$ buckets for the surface application treatments. To ensure uniform distribution following tillage on the plots where manure was incorporated, the manure application covered an area slightly larger than the final plot dimensions. A $5 \mathrm{~m}$ tandem disc was used to incorporate the applied manure to a depth of approximately $8 \mathrm{~cm}$. A single tillage pass occurred up and down the slope in the direction of overland flow within approximately $30 \mathrm{~min}$ after manure application.

Flux measurements were taken during two test periods under saturated (day 1) and wet (day 2) soil water conditions.

Table 3. Summary of measured compounds, method detection limits (MDL), calibration statistics, and background soil emission rates under dry and wet soil water conditions.

\begin{tabular}{|c|c|c|c|c|c|c|c|c|c|c|c|}
\hline \multirow[b]{2}{*}{ Compound } & \multirow{2}{*}{$\begin{array}{c}\text { Molecular } \\
\text { Weight }\end{array}$} & \multirow{2}{*}{$\begin{array}{l}\text { Retention } \\
\text { Time } \\
\text { (min) }\end{array}$} & \multirow{2}{*}{$\begin{array}{l}\text { Min. } \\
\text { (ng) }\end{array}$} & \multirow{2}{*}{$\begin{array}{c}\text { Max. } \\
\text { (ng) }\end{array}$} & \multirow{2}{*}{$\begin{array}{c}\text { MDL } \\
(\mathrm{ng})\end{array}$} & \multirow{2}{*}{$\begin{array}{c}\mathrm{MDL}^{[\mathrm{a}]} \\
\left(\mu \mathrm{g} \mathrm{m}^{-2} \min ^{-1}\right)\end{array}$} & \multirow[b]{2}{*}{$\mathrm{RSD}^{[\mathrm{b}]}$} & \multirow[b]{2}{*}{$\mathrm{r}^{2}$} & \multicolumn{2}{|c|}{$\begin{array}{c}\text { Background } \\
\text { Emission } \\
\left(\mu \mathrm{g} \mathrm{m}^{-2} \mathrm{~min}^{-1}\right)\end{array}$} & \multirow{2}{*}{$\begin{array}{c}\text { Relative } \\
\text { Contribution } \\
\text { to } \mathrm{OAV}^{[\mathrm{e}]} \\
(\%)\end{array}$} \\
\hline & & & & & & & & & Dry $^{[\mathrm{c}]}$ & $\mathrm{Wet}^{[\mathrm{d}]}$ & \\
\hline \multicolumn{12}{|l|}{ Volatile fatty acids } \\
\hline Acetic acid & 60.0 & 12.4 & 30.2 & 4114 & 32.9 & 0.16 & 0.38 & 0.99 & 0.33 & 0.67 & 0.86 \\
\hline Butyric acid & 88.1 & 15.1 & 2.9 & 3723 & 8.6 & 0.042 & 0.87 & 0.99 & 0.03 & 0.04 & 0.56 \\
\hline Heptanoic acid & 130.2 & 19.5 & 0.66 & 502 & 1.6 & 0.0077 & 0.25 & 0.98 & 0.02 & 0.02 & 23.5 \\
\hline Hexanoic acid & 116.2 & 18.1 & 5.3 & 8244 & 2.2 & 0.011 & 0.50 & 0.98 & 0.08 & 0.08 & 17.6 \\
\hline Isobutyric acid & 88.1 & 14.2 & 2.4 & 2239 & 15.1 & 0.073 & 0.82 & 0.99 & 0.01 & 0.01 & 9.26 \\
\hline Isovaleric acid & 102.1 & 15.7 & 0.57 & 1810 & 5.9 & 0.028 & 0.80 & 0.99 & 0.00 & 0.01 & 3.39 \\
\hline Propanoic acid & 74.1 & 13.8 & 4.2 & 6721 & 15.9 & 0.077 & 0.89 & 0.99 & 0.04 & 0.13 & 0.87 \\
\hline Valeric acid & 102.1 & 16.7 & 1.9 & 807 & 2.5 & 0.012 & 0.62 & 0.99 & 0.02 & 0.03 & 1.13 \\
\hline \multicolumn{12}{|l|}{ Aromatics } \\
\hline 4-Ethylphenol & 122.2 & 22.2 & 0.07 & 7.66 & 6.0 & 0.029 & 0.20 & 0.97 & 0.00 & 0.00 & 1.21 \\
\hline 4-Methylphenol & 108.1 & 21.1 & 0.37 & 871 & 4.0 & 0.019 & 0.11 & 0.97 & 0.00 & 0.01 & 1.22 \\
\hline Indole & 117.1 & 25.2 & 0.07 & 259 & 3.5 & 0.017 & 0.09 & 0.99 & 0.00 & 0.00 & 14.7 \\
\hline Phenol & 94.1 & 20.2 & 5.0 & 2027 & 6.0 & 0.029 & 0.14 & 0.99 & 0.04 & 0.07 & 1.66 \\
\hline Skatole & 131.2 & 25.6 & 0.015 & 9.84 & 4.8 & 0.023 & 0.12 & 0.98 & 0.00 & 0.00 & 8.84 \\
\hline \multicolumn{12}{|l|}{ Sulfides } \\
\hline Dimethyl disulfide & 94.2 & 5.2 & 2.4 & 1281 & 1.0 & 0.005 & 0.04 & 0.99 & 0.01 & 0.01 & 9.50 \\
\hline Dimethyl trisulfide & 126.2 & 11.0 & 0.40 & 587 & 2.1 & 0.01 & 0.14 & 0.99 & 0.00 & 0.00 & 5.68 \\
\hline
\end{tabular}

[a] Method detection limit for flux based on a 60 min sample with a wind tunnel flow rate of $1 \mathrm{~L} \mathrm{~min}^{-1}$.

[b] Relative standard deviation (SD/mean) from seven replications at minimum mass analyzed.

[c] Background emission rate from soil receiving no water or beef manure (mean of three replicates).

[d] Background emission rate from soil receiving water but no beef manure (mean of three replicates).

[e] Relative contributions to total OAV are means obtained across all experimental variables. 
An irrigation system was constructed that allowed water to be sprayed at a low rate onto the plot surface during day 1 . The application intensity was adjusted so that the plot surface remained saturated, but runoff did not occur. VOC measurements were taken at $0,1,2,6$, and $23 \mathrm{~h}$ on day 1 (saturated soil water condition). The flux measurements obtained during day 1 can be used to determine if VOC emissions are impacted by extended periods of rainfall when saturated soil water conditions are present. The irrigation system was removed at the end of day 1 . The effects of drying on VOC emissions were measured during the next $24 \mathrm{~h}$ (day 2, wet soil water condition) at 24, 25, 26, 30, and $47 \mathrm{~h}$ after manure application.

\section{Wind Tunnel Flux Measurements}

Flux measurements were made using six wind tunnels, one per plot within a given treatment block (fig. 2). Details on the operation of the small wind tunnels are provided by Parker et al. (2013b). Each wind tunnel had a $51 \mathrm{~mm}$ height, $305 \mathrm{~mm}$ length, and $152 \mathrm{~mm}$ width, with a footprint of $0.046 \mathrm{~m}^{2}$ and internal volume of $2.36 \mathrm{~L}$. The sweep air entered the wind tunnel through 17 holes $(6 \mathrm{~mm}$ diameter) in three rows at heights of $17 \mathrm{~mm}$ ( 6 holes), $30 \mathrm{~mm}$ ( 5 holes), and $43 \mathrm{~mm}$ ( 6 holes) above the base. Air exited the wind tunnel through three $10 \mathrm{~mm}$ diameter holes equally spaced at a height of $27 \mathrm{~mm}$ above the surface at the opposite end of the tunnel. Sweep air $\left(1 \mathrm{~L} \mathrm{~min}^{-1}\right)$ was supplied via Teflon tubing from a compressed air cylinder (Linweld, Lincoln, Neb.).

The wind tunnel was placed on the plot surface and pressed into the soil to establish a seal around the base of the tunnel. After an equilibration period of $21 \mathrm{~min}$ that allowed three volumes of sweep air to pass through the wind tunnel, VOC samples were collected from the air exiting the wind tunnel. Air samples were obtained in stainless steel sorbent tubes $(89 \mathrm{~mm} \times 6.4 \mathrm{~mm}$ outside diameter, Markes International, Bridgend, U.K.) filled with Tenax TA sorbent (Sigma-Aldrich, St. Louis, Mo.). Prior to use, the sorbent tubes were conditioned for $30 \mathrm{~min}$ at $230^{\circ} \mathrm{C}$. Air was pulled through the sorbent tubes at a flow rate of $75 \mathrm{~mL} \mathrm{~min}^{-1}$ for 60 min using a vacuum pump (Pocket Pump 210 Series, SKC, Covington, Ga.).

Flux density $(J)$ was calculated on a mass per unit area per unit time basis $\left(\mu \mathrm{g} \mathrm{m}^{-2} \mathrm{~min}^{-1}\right)$ using equation 1 :

$$
J=\frac{Q C_{a i r}}{A}
$$

where $Q$ is the sweep airflow rate $\left(\mathrm{m}^{3} \mathrm{~min}^{-1}\right), C_{a i r}$ is the VOC concentration of the exiting air $\left(\mu \mathrm{g} \mathrm{m}^{-3}\right)$, and $A$ is the footprint of the wind tunnel $\left(\mathrm{m}^{2}\right)$.

Air samples for VOC measurements were taken at $0,1,2$, 6 , and $23 \mathrm{~h}$ after manure application for the saturated soil water condition (day 1) and at 24, 25, 26, 30, and $47 \mathrm{~h}$ after manure application for the wet soil water condition (day 2). The irrigation system was turned off to prevent the vacuum pumps from becoming saturated during the period required to obtain VOC measurements on day 1 . After the VOC samples were collected for a given sampling period on day 1 , all of the sampling equipment was removed from the plots and irrigation was resumed until the next sampling interval. The wind tunnel was placed on different sections of the plot during each sampling interval on days 1 and 2 . The same VOC sampling equipment, test intervals, and air sampling protocols were used on days 1 and 2 .

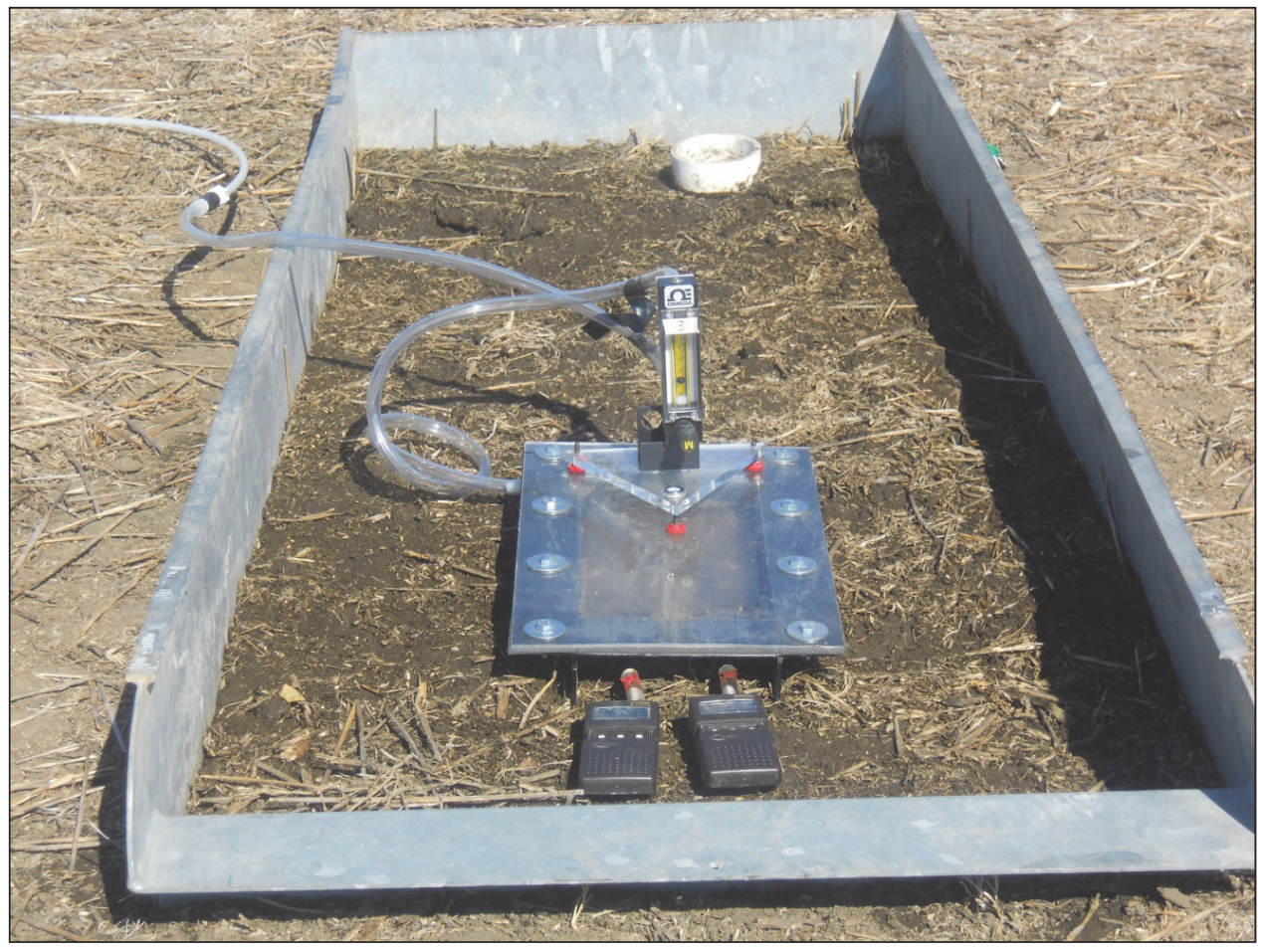

Figure 2. Wind tunnel and gas sampling equipment used during the study. Air samples were obtained in duplicate. The cover used to shade the wind tunnel from direct sunlight was removed when the photograph was taken. 


\section{GAS CHROMATOGRAPHY/MASS SPECTROMETRY}

Sorbent tube samples were collected in duplicate on each plot. Two blocks were included in the experimental design (fig. 1); therefore, four measurements were obtained for a given soil water condition and sampling interval. The four measurements were treated as repeated measures in the statistical analyses.

A thermal desorption gas chromatography/mass spectrometry (TD GC/MS) system consisting of a Unity 2 thermal desorber with Ultra 2 autosampler (Markes International, Bridgend, U.K.) was used to analyze the sorbent tube samples. Samples were quantified with an Agilent GC/MS system (7890A/5975C, Agilent Technologies, Santa Clara, Cal.). The system used an Innowax $(30 \mathrm{~m} \times 0.25 \mathrm{~mm}$ inner diameter) polar capillary column (polyethylene glycol, $0.25 \mathrm{~mm}$ film thickness) that was operated at a constant airflow rate of $1.4 \mathrm{~mL} \mathrm{~min}{ }^{-1}$.

Samples were purged for $1 \mathrm{~min}$ at $40 \mathrm{~mL} \mathrm{~min}{ }^{-1}$ to remove water and solvent. The tube was then desorbed for $10 \mathrm{~min}$ at $280^{\circ} \mathrm{C}$ with an ultra-high purity helium (carrier gas) flow of $50 \mathrm{~mL} \mathrm{~min}{ }^{-1}$ and trapped on a cold trap maintained at $-10^{\circ} \mathrm{C}$. The cold trap was heated to $320^{\circ} \mathrm{C}$ for 1 min with a helium flow of $20 \mathrm{~mL} \mathrm{~min}^{-1}$, and $1.4 \mathrm{~mL} \mathrm{~min}^{-1}$ was transferred to the GC/MS system. The column was held at $40^{\circ} \mathrm{C}$ for $3 \mathrm{~min}$ in the $\mathrm{GC}$ oven, and then the temperature was increased to $230^{\circ} \mathrm{C}$ at a rate of $8^{\circ} \mathrm{C} \mathrm{min}^{-1}$ and held at $230^{\circ} \mathrm{C}$ for $5 \mathrm{~min}$.

Samples were analyzed for three basic categories of compounds: VFA, aromatics, and volatile sulfur compounds (VSC). The compounds were selected based on the constituents that were most prevalent in our previous sorbent tube studies on emissions from beef cattle manure (Woodbury et al., 2014). The eight VFA were ethanoic (acetic), butanoic (butyric), heptanoic, hexanoic, 2-methylpropanoic (isobutyric), 3-methylbutanoic (isovaleric), propionic, and pentanoic (valeric) acids. For the remainder of this article, the more common names for the fatty acids (shown in parentheses) will be used. The five aromatic compounds were 4-ethylphenol, 4-methylphenol, indole, phenol, and skatole. The two sulfur-containing VOC were dimethyl disulfide (DMDS) and dimethyl trisulfide (DMTS).

Calibration standard solutions were prepared by diluting known masses of pure chemicals with methanol. The standards were prepared and analyzed within $48 \mathrm{~h}$ to establish standard curves. The prepared standards were periodically checked with stored standards to identify any changes in sensitivity of the analysis. All chemicals and solvents were FCC grade (Sigma Aldrich, St. Louis, Mo.). Standards were prepared using serial dilutions and then injected onto clean tubes while purified air was pulled through the tubes with a vacuum pump operated at $75 \mathrm{~mL} \mathrm{~min}{ }^{-1}$. The standard solutions were stored for periodic instrument calibrations.

Our experience has shown little evidence that VFA are ionized and become nonvolatile. We have seen nearly identical GC responses from freshly made standards when compared to standards that have been stored, which indicates minimal ionization or response issues. Within the linear range, standard curves were fit using linear regression with zero $y$-intercept. Coefficients of determination $\left(\mathrm{r}^{2}\right)$ for the standard curves ranged from $97.8 \%$ to $99.7 \%$ for the eight
VFA, from $97.8 \%$ to $99.3 \%$ for the five aromatics, and were $99.8 \%$ for both DMDS and DMTS.

Andersen et al. (2012) showed that thermal desorption procedures similar to those used in this study can dimerize methanethiol (MT) to other VSC such as DMDS and DMTS. Because MT is sometimes reported in manure in anaerobic environments, it is difficult to definitively quantify whether VSC emissions are MT, DMDS, DMTS, or a combination of these constituents. For this reason, we estimated odor impacts as discussed in the following section using two methods: first using measured DMDS and DMTS concentrations, and second assuming that an equal mass of methanethiol was converted to DMDS and/or DMTS.

\section{OdOR ACTIVITY VALUES AND ANALYSES}

Concentrations of individual compounds were converted to their respective odor activity values (OAV). An assessment of the relative impact of each individual odor compound is provided by OAV analyses. Details on the conversion are provided by Parker et al. (2013a); a brief description is provided below.

The OAV is a ratio of the measured concentration of a single compound normalized to the single-compound odor threshold (SCOT) for that compound (Patton and Josephson, 1957; Friedrich and Acree, 1998; Trabue et al., 2006; Parker et al., 2010, 2013b). Therefore, the larger the OAV for an individual compound, the more likely that compound will contribute to the overall odor of a complex odor mixture.

The SCOT values for each compound were obtained from published odor thresholds (table 4). The relative contribution of each compound was calculated by subtracting the background emission for each compound and dividing by the sum of the OAV for all measured compounds. This approach does not account for possible synergistic or other complex interactions of the compounds (DiSpirito et al., 1994; Powers, 2001; Zahn et al., 2001).

\section{STATISTICAL ANALYSES}

The effects of diet, land application method, soil water condition, and time since manure application on VOC measurements were determined using ANOVA (SAS, 2011). The MIXED procedure of SAS was used in the analyses, and the subsample error was adjusted out of the error term. The restricted maximum likelihood approach was used to provide estimates, and the profile method was used to concentrate the residual variance out of the optimization problem.

For a given plot, duplicate readings collected for a particular test interval and sample collection time were treated as repeated measures. Significant treatment differences were further evaluated using post-hoc protected multiple comparison tests (Fisher's LSD). A probability level of $\leq 0.05$ was considered significant.

\section{RESULTS AND DISCUSSION}

Contributions to total OAV are averages obtained across all diets, land application methods, soil water conditions, and time since manure application. VFA with notable contributions to total OAV included heptanoic, hexanoic, isobutyric, 
Table 4. Summary of published single-compound odor thresholds (SCOT) for the 15 compounds measured in this study. Different statistical measures of central tendency are provided. All raw data on thresholds are from van Gemert (2003) unless otherwise noted.

\begin{tabular}{|c|c|c|c|c|c|c|c|c|c|c|}
\hline \multicolumn{2}{|c|}{ Compound } & \multirow{2}{*}{$\frac{N^{[\mathrm{a}]}}{8}$} & \multirow{2}{*}{$\frac{\begin{array}{c}\text { Minimum } \\
\left(\mu \mathrm{g} \mathrm{m}^{-3}\right)\end{array}}{25}$} & \multirow{2}{*}{$\begin{array}{c}\text { Maximum } \\
\left(\mu \mathrm{g} \mathrm{m}^{-3}\right)\end{array}$} & \multirow{2}{*}{$\begin{array}{c}\begin{array}{c}\text { Arithmetic } \\
\text { Mean } \\
\left(\mu \mathrm{g} \mathrm{m}^{-3}\right)\end{array} \\
2480\end{array}$} & \multirow{2}{*}{$\begin{array}{c}\begin{array}{c}\text { Standard } \\
\text { Deviation } \\
\left(\mu \mathrm{g} \mathrm{m}^{-3}\right)\end{array} \\
2754\end{array}$} & \multirow{2}{*}{$\begin{array}{c}\begin{array}{c}\text { Geometric } \\
\text { Mean } \\
\left(\mu \mathrm{g} \mathrm{m}^{-3}\right)\end{array} \\
578\end{array}$} & \multirow{2}{*}{$\begin{array}{c}\begin{array}{c}\text { Harmonic } \\
\text { Mean } \\
\left(\mu \mathrm{g} \mathrm{m}^{-3}\right)\end{array} \\
85\end{array}$} & \multirow{2}{*}{$\begin{array}{c}\begin{array}{c}\text { Median } \\
\left(\mu \mathrm{g} \mathrm{m}^{-3}\right)\end{array} \\
2050\end{array}$} & \multirow{2}{*}{$\begin{array}{c}\begin{array}{l}\text { Geometric } \\
\text { Mean }^{[\mathrm{b}]}\end{array} \\
467\end{array}$} \\
\hline Volatile fatty acids & Acetic acid & & & & & & & & & \\
\hline & Butyric acid & 11 & 0.4 & 105 & 25 & 34 & 6.9 & 1.4 & 13 & 23 \\
\hline & Heptanoic acid & 3 & 22 & 300 & 118 & 157 & 60 & 38 & 3 & - \\
\hline & Hexanoic acid & 5 & 12 & 510 & 182 & 226 & 69 & 31 & 40 & 83.1 \\
\hline & Isobutyric acid & 2 & 0.8 & 285 & 145 & 198 & 38 & 10 & 145 & 41 \\
\hline & Isovaleric acid & 5 & 0.22 & 14 & 5 & 5.5 & 2.3 & 0.81 & 4.1 & 4.7 \\
\hline & Propionic acid & 7 & 3 & 890 & 303 & 344 & 106 & 18 & 80 & 101 \\
\hline & Valeric acid & 6 & 0.8 & 75 & 24 & 30 & 8.8 & 3 & 9 & 11.7 \\
\hline \multirow[t]{5}{*}{ Aromatics $^{[\mathrm{c}]}$} & 4-Ethylphenol & 1 & 6.3 & 6.3 & 6.3 & - & 6.3 & 6.3 & 6.3 & - \\
\hline & 4-Methylphenol & 4 & 0.05 & 24 & 9.2 & 11.5 & 1.3 & 0.16 & 6.3 & 2.6 \\
\hline & Indole & 2 & 0.6 & 7.1 & 3.8 & 4.6 & 2.1 & 1.1 & 3.8 & 1.9 \\
\hline & Phenol & 9 & 39 & 4000 & 734 & 1290 & 206 & 88 & 200 & 127 \\
\hline & Skatole & 4 & 0.35 & 0.78 & 0.51 & 0.19 & 0.48 & 0.46 & 0.45 & 1.6 \\
\hline \multirow[t]{2}{*}{ Sulfides } & DMDS & 5 & 1.6 & 64 & 25 & 28 & 12 & 5.3 & 8.5 & - \\
\hline & DMTS & 3 & 0.08 & 14 & 7.2 & 7 & 2 & 0.24 & 7.5 & - \\
\hline
\end{tabular}

and isovaleric acids, with contributions of $23.5 \%, 17.6 \%$, $9.26 \%$, and $3.39 \%\left(0.034,0.258,0.030\right.$, and $0.014 \mu \mathrm{g} \mathrm{m}^{-2}$ $\mathrm{min}^{-1}$ ), respectively (tables 3 and 5). Trabue et al. (2011) also reported that VFA were the most abundant of the major odorants from beef cattle feedlots.

The two aromatics that contributed substantially to total OAV were indole and skatole, with values of $14.7 \%$ and $8.84 \%\left(0.005\right.$ and $\left.0.0004 \mu \mathrm{g} \mathrm{m}^{-2} \mathrm{~min}^{-1}\right)$, respectively (tables 3 and 5). The sulfides (DMDS and DMTS) contributed $9.50 \%$ and $5.68 \%\left(0.013\right.$ and $\left.0.030 \mu \mathrm{g} \mathrm{m}^{-2} \mathrm{~min}^{-1}\right)$ to total OAV. Acetic acid, butyric acid, propanoic acid, valeric acid, 4-ethylphenol, 4-methylphenol, and phenol each had contributions that were less than $2 \%$ of the total measured OAV and are not included in further discussion. Measured values for isobutyric acid, isovaleric acid, indole, and skatole were in some cases less than the minimum detection limit.

With the exception of heptanoic acid, emissions of each of the measured VOC were greater from the plots where manure was surface-applied (table 5). The ratio of VOC emissions from the surface-applied to incorporated plots ranged from 1.00 for heptanoic acid to 11.0 for DMTS. Woodbury et al. (2014) also noted larger emissions from sites where beef cattle manure was surface-applied rather than incorporated.

Emission of DMDS for the $30 \%$ WDGS diet was $0.318 \mu \mathrm{g} \mathrm{m}^{-2} \mathrm{~min}^{-1}$, compared to emissions of 0.032 and $0.053 \mu \mathrm{g} \mathrm{m}^{-2} \mathrm{~min}^{-1}$, respectively, for the $0 \%$ and $10 \%$ WDGS diets (table 5). Similarly, emission of DMTS was $0.074 \mu \mathrm{g}$ $\mathrm{m}^{-2} \mathrm{~min}^{-1}$ for the $30 \%$ WDGS diet, compared to emissions of 0.007 and $0.008 \mu \mathrm{g} \mathrm{m}^{-2} \mathrm{~min}^{-1}$, respectively, for the $0 \%$ and $10 \%$ WDGS diets. Larger emissions of the sulfur compounds for the $30 \%$ WDGS diet were also noted by Woodbury et al. (2014).

Flux measurements for each VOC were greater under saturated soil water conditions than under wet conditions (table 5). The ratio of VOC emissions from saturated to wet soil water conditions ranged from 1.27 for heptanoic and hexanoic acids to 8.00 for indole. VOC flux values decreased

Table 5. Odorous volatile organic compound emissions as affected by application method, diet, soil water condition, and time since manure application. Values listed for a variable are averaged across all other variables. Means in the same column followed by different letters are significantly different at the 0.05 probability level bases on LSD test.

\begin{tabular}{|c|c|c|c|c|c|c|c|c|}
\hline & \multicolumn{4}{|c|}{$\begin{array}{l}\text { Volatile Fatty Acids } \\
\left(\mu \mathrm{g} \mathrm{m}^{-2} \mathrm{~min}^{-1}\right)\end{array}$} & \multicolumn{2}{|c|}{$\begin{array}{c}\text { Aromatics } \\
\left(\mu \mathrm{g} \mathrm{m}^{-2} \mathrm{~min}^{-1}\right)\end{array}$} & \multicolumn{2}{|c|}{$\begin{array}{c}\text { Sulfides } \\
\left(\mu \mathrm{g} \mathrm{m}^{-2} \mathrm{~min}^{-1}\right)\end{array}$} \\
\hline & Heptanoic & Hexanoic & Isobutyric & Isovaleric & Indole & Skatole & DMDS & DMTS \\
\hline \multicolumn{9}{|l|}{ Application method } \\
\hline Surface-applied & 0.034 & 0.268 & 0.036 & 0.018 & 0.007 & 0.0004 & 0.241 & 0.055 \\
\hline Incorporated & 0.034 & 0.248 & 0.023 & 0.009 & 0.002 & 0.0003 & 0.028 & 0.005 \\
\hline \multicolumn{9}{|l|}{ Diet } \\
\hline $0 \%$ WDGS & 0.033 & 0.264 & 0.028 & 0.009 & 0.002 & 0.0004 & 0.032 & 0.007 \\
\hline $10 \%$ WDGS & 0.040 & 0.281 & 0.026 & 0.011 & 0.006 & 0.0003 & 0.053 & 0.008 \\
\hline $30 \%$ WDGS & 0.029 & 0.230 & 0.035 & 0.021 & 0.006 & 0.0004 & 0.318 & 0.074 \\
\hline \multicolumn{9}{|l|}{ Soil water condition } \\
\hline Saturated & 0.038 & 0.289 & 0.038 & 0.016 & 0.008 & $0.0005 \mathrm{a}$ & 0.219 & 0.050 \\
\hline Wet & 0.030 & 0.227 & 0.021 & 0.011 & 0.001 & $0.0002 \mathrm{~b}$ & 0.050 & 0.010 \\
\hline \multicolumn{9}{|c|}{ Time since application $^{[\mathrm{a}]}$} \\
\hline $0 \mathrm{~h}(24)$ & 0.044 & 0.344 & 0.053 & 0.014 & 0.007 & 0.0005 & 0.143 & 0.034 \\
\hline $1 \mathrm{~h}(25)$ & 0.038 & 0.312 & 0.025 & 0.015 & 0.007 & 0.0004 & 0.234 & 0.047 \\
\hline $2 \mathrm{~h}(26)$ & 0.021 & 0.165 & 0.022 & 0.012 & 0.005 & 0.0003 & 0.138 & 0.041 \\
\hline $6 \mathrm{~h}(30)$ & 0.039 & 0.240 & 0.021 & 0.014 & 0.002 & 0.0003 & 0.123 & 0.021 \\
\hline $23 \mathrm{~h}(47)$ & 0.028 & 0.228 & 0.027 & 0.012 & 0.001 & 0.0002 & 0.035 & 0.006 \\
\hline
\end{tabular}

[a] Sampling of VOC emissions under saturated soil water conditions began immediately after manure application,

while sampling under wet soil water conditions began $24 \mathrm{~h}$ later (at the times shown in parentheses). 
substantially by the end of the test period. The isobutyric acid flux of $0.053 \mu \mathrm{g} \mathrm{m}^{-2} \mathrm{~min}^{-1}$ collected initially was greater than the measurements obtained during the later sampling intervals, which varied from 0.021 to $0.027 \mu \mathrm{g} \mathrm{m}^{-2} \mathrm{~min}^{-1}$.

\section{Volatile FatTy ACIDS}

Mean emissions of heptanoic, hexanoic, isobutyric, and isovaleric acids were $0.034,0.258,0.030$, and $0.014 \mu \mathrm{g} \mathrm{m}^{-2}$ $\mathrm{min}^{-1}$, respectively. A significant interaction among diet, application method, soil water condition, and time since manure application was found for heptanoic acid (table 6). An heptanoic acid flux value of $0.103 \mu \mathrm{g} \mathrm{m}^{-2} \mathrm{~min}^{-1}$ occurred on the plots where manure from the $10 \%$ WDGS diet was surface-applied (fig. 3). Heptanoic acid emissions usually peaked at the 0 or $1 \mathrm{~h}$ sampling periods, and variations in flux values were usually minimal among the other sampling intervals. The results obtained for heptanoic acid were similar to those found for hexanoic, isobutyric, and isovaleric acids. Woodbury et al. (2014) noted that the largest hexanoic acid emissions occurred on plots where manure from the $10 \%$ WDGS diet was applied.

\section{Aromatics}

The two aromatics that contributed substantially to total $\mathrm{OAV}$ were indole and skatole. The flux values for indole and skatole were 0.007 and $0.0004 \mu \mathrm{g} \mathrm{m}^{-2} \mathrm{~min}^{-1}$, respectively, when manure was surface-applied compared to 0.002 and $0.0003 \mu \mathrm{g} \mathrm{m}^{-2} \mathrm{~min}^{-1}$, respectively, for incorporated manure. The skatole emission of $0.0005 \mu \mathrm{g} \mathrm{m}^{-2} \mathrm{~min}^{-1}$ obtained under saturated soil water conditions was significantly greater than the $0.0002 \mu \mathrm{g} \mathrm{m}^{-2} \mathrm{~min}^{-1}$ obtained under wet conditions. The flux values of 0.007 and $0.0005 \mu \mathrm{g} \mathrm{m}^{-2} \mathrm{~min}^{-1}$ for indole and skatole, respectively, at the initiation of the tests were substantially greater than the corresponding values of 0.001 and $0.0002 \mu \mathrm{g} \mathrm{m}^{-2} \mathrm{~min}^{-1}$ obtained at the end of the sampling period.

\section{SULFIDES}

The emission trends for DMDS and DMTS were similar. A DMDS emission of $0.241 \mu \mathrm{g} \mathrm{m}^{-2} \mathrm{~min}^{-1}$ was obtained on the plots where manure was surface-applied compared to $0.028 \mu \mathrm{g} \mathrm{m}^{-2} \mathrm{~min}^{-1}$ on the plots where manure was incorporated. DMTS flux values of 0.055 and $0.005 \mu \mathrm{g} \mathrm{m}^{-2}$ $\min ^{-1}$ were measured on the plots where manure was surfaceapplied and incorporated, respectively. Higher sulfide emission rates on the plots where manure was surface-applied occurred because of increased sulfide production on the soil surface.

The application of manure from a diet containing $30 \%$ WDGS resulted in a DMDS flux of $0.318 \mu \mathrm{g} \mathrm{m}^{-2} \mathrm{~min}^{-1}$ compared to the values of 0.032 and $0.053 \mu \mathrm{g} \mathrm{m}^{-2} \mathrm{~min}^{-1}$, respectively, for the $0 \%$ and $10 \%$ WDGS diets. The DMDS flux of $0.219 \mu \mathrm{g} \mathrm{m}^{-2} \mathrm{~min}^{-1}$ obtained under saturated soil water conditions was greater than the $0.050 \mu \mathrm{g} \mathrm{m}^{-2} \mathrm{~min}^{-1} \mathrm{ob}-$ tained under wet conditions.

The removal of the starch component of corn during the distillation process concentrates many of the conserved elements in the byproduct. Sulfur compounds may also be added during processing, which increases the sulfur content of the diet. WDGS are highly digested and have a higher sulfur concentration, which may result in rapid conversion to sulfide compounds under anaerobic conditions (Spiehs and Varel, 2009; Varel et al., 2010).

An increase in sulfide flux rates with time may also have been influenced by a reduction in the oxidation status of saturated soils, which favors the formation of sulfur compounds. Sulfides can be produced under anaerobic conditions for wet soil water conditions. Woodbury et al. (2014, 2016) reported the largest DMDS emissions under wet soil water conditions.

\section{Comparisons With Previous Studies}

Woodbury et al. (2014) measured VOC emissions after land application of manure from diets containing $0 \%, 10 \%$, or $30 \%$ WDGS. Their study was conducted on a site where manure was either surface-applied or incorporated to meet the one-year $\mathrm{N}$ requirement for corn. In contrast to the present study, a single application of water was applied $24 \mathrm{~h}$ after manure application (at the beginning of day 2). The principal odorous VOC emissions that occurred during day 2 (wet soil water condition, table 5 of Woodbury et al., 2014) were VFA including butyric acid $\left(0.127 \mu \mathrm{g} \mathrm{m}^{2} \mathrm{~min}^{-1}\right)$, hexanoic acid $\left(1.52 \mu \mathrm{g} \mathrm{m}^{2} \mathrm{~min}^{-1}\right)$, isobutyric acid $\left(0.050 \mu \mathrm{g} \mathrm{m}^{2}\right.$ $\left.\min ^{-1}\right)$, isovaleric acid $\left(0.052 \mu \mathrm{g} \mathrm{m}^{2} \min ^{-1}\right)$, propanoic acid

Table 6. Analysis of variance results $(\mathrm{Pr}>\mathrm{F})$ as affected by application method, diet, soil water condition, and time since application. ${ }^{\text {[a] }}$

\begin{tabular}{|c|c|c|c|c|c|c|c|c|}
\hline \multirow[b]{2}{*}{ Factors and Interactions } & \multicolumn{4}{|c|}{ Volatile Fatty Acids } & \multicolumn{2}{|c|}{ Aromatic } & \multicolumn{2}{|c|}{ Sulfides } \\
\hline & Heptanoic & Hexanoic & Isobutyric & Isovaleric & Indole & Skatole & DMDS & DMTS \\
\hline Application method & 0.95 & 0.80 & 0.24 & 0.32 & 0.21 & 0.52 & 0.13 & 0.21 \\
\hline Diet & 0.62 & 0.85 & 0.75 & 0.56 & 0.72 & 0.62 & 0.18 & 0.29 \\
\hline Soil water condition & 0.36 & 0.30 & 0.10 & 0.10 & 0.07 & $0.03 *$ & 0.07 & 0.16 \\
\hline Time & 0.27 & 0.25 & 0.06 & 0.90 & 0.12 & 0.13 & 0.47 & 0.46 \\
\hline Application method $\times$ Diet & 0.37 & 0.26 & 0.62 & 0.50 & 0.55 & 0.68 & 0.18 & 0.28 \\
\hline Application method $\times$ Soil water condition & 0.73 & 0.86 & 0.31 & 0.74 & 0.20 & 0.62 & 0.10 & 0.20 \\
\hline Diet $\times$ Soil water condition & 0.66 & 0.95 & 0.39 & 0.72 & 0.71 & 0.48 & 0.13 & 0.25 \\
\hline Application method $\times$ Diet $\times$ Soil water condition & 0.27 & 0.25 & 0.65 & 0.80 & 0.55 & 0.60 & 0.13 & 0.24 \\
\hline Application method $\times$ Time & 0.90 & 0.65 & 0.42 & 0.81 & 0.43 & 0.53 & 0.51 & 0.52 \\
\hline Diet $\times$ Time & 0.33 & 0.50 & 0.79 & 0.80 & 0.35 & 0.93 & 0.71 & 0.67 \\
\hline Application method $\times$ Diet $\times$ Time & 0.58 & 0.65 & 0.72 & 0.93 & 0.49 & 0.65 & 0.68 & 0.61 \\
\hline Soil water condition $\times$ Time & 0.63 & 0.46 & 0.22 & 0.11 & 0.11 & 0.31 & 0.56 & 0.53 \\
\hline Application method $\times$ Soil water condition $\times$ Time & 0.67 & 0.67 & 0.54 & 0.24 & 0.38 & 0.45 & 0.58 & 0.59 \\
\hline Diet $\times$ Soil water condition $\times$ Time & 0.78 & 0.90 & 0.47 & 0.11 & 0.44 & 0.91 & 0.77 & 0.68 \\
\hline Application method $\times$ Diet $\times$ Soil water condition $\times$ Time & $0.05^{*}$ & 0.09 & 0.74 & 0.12 & 0.48 & 0.31 & 0.73 & 0.63 \\
\hline
\end{tabular}

[a] Asterisks $(*)$ indicate significance at the 0.05 probability level. 


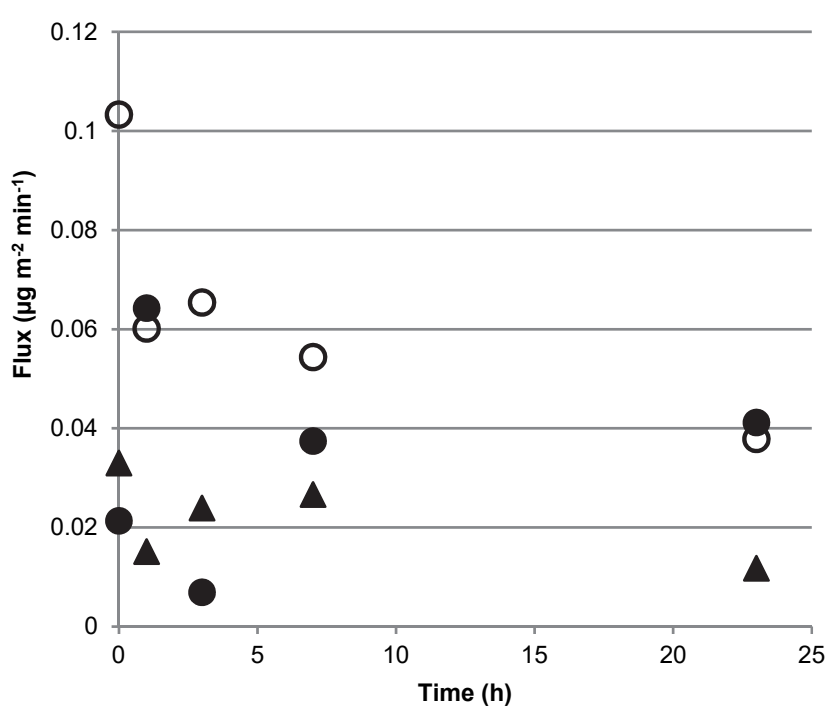

(a) Surface-applied manure on day 1

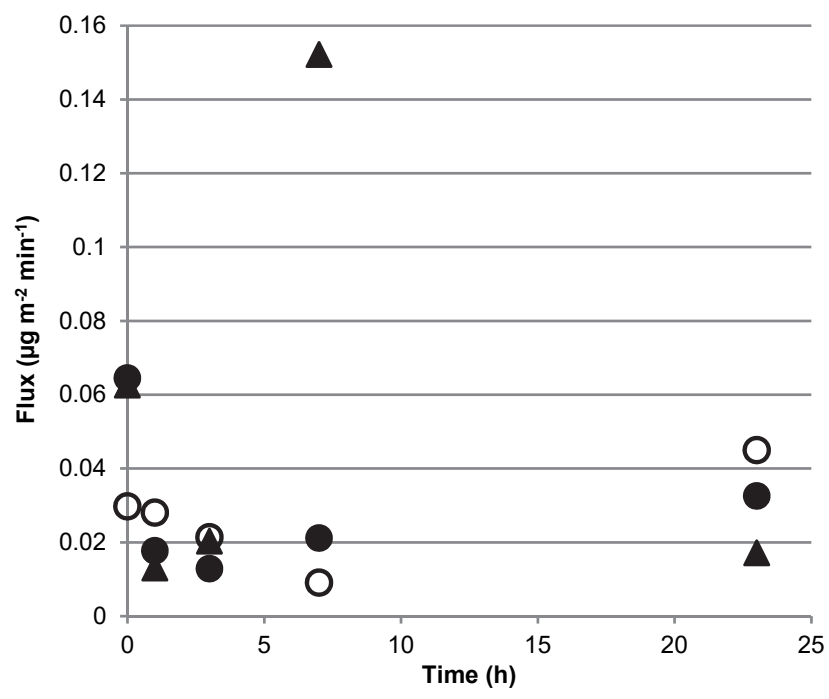

(c) Incorporated manure on day 1

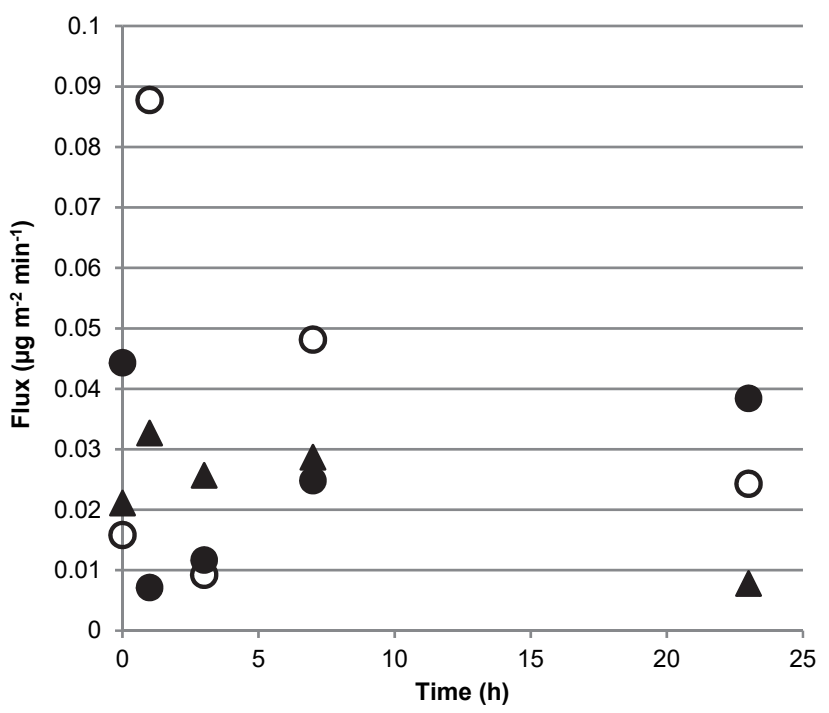

(b) Surface-applied manure on day 2

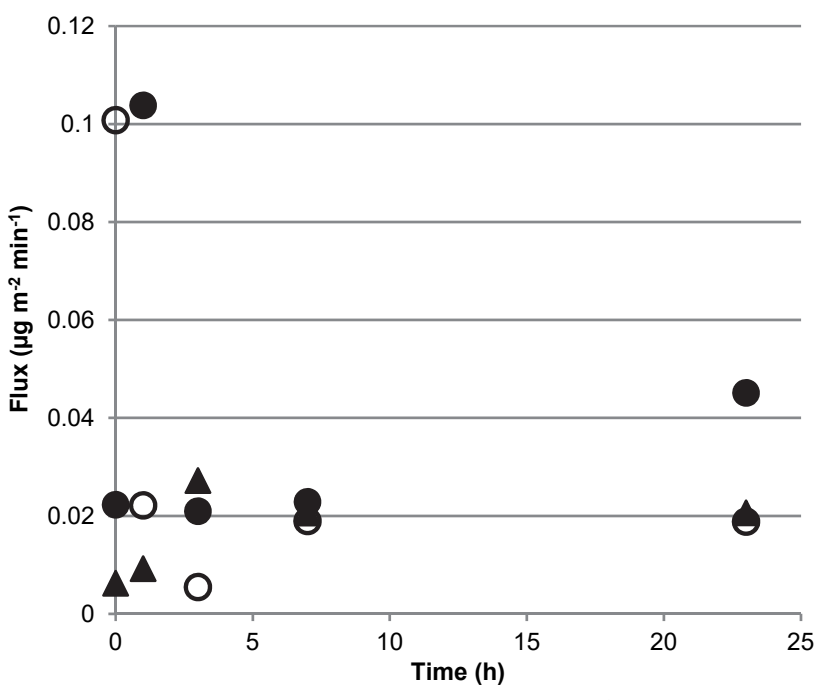

(d) Incorporated manure on day 2

Figure 3. Heptanoic acid flux as affected by diet and time for surface-applied manure under (a) saturated soil water conditions on day 1 and (b) wet soil water conditions on day 2 and for incorporated manure under (c) saturated soil water conditions on day 1 and (d) wet soil water conditions on day $2(-0 \%$ WDGS, $\bigcirc=10 \%$ WDGS, and $\triangle=30 \%$ WDGS).

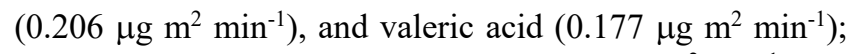
aromatics including 4-methylphenol $\left(0.056 \mu \mathrm{g} \mathrm{m}^{2} \mathrm{~min}^{-1}\right)$ and indole $\left(0.017 \mu \mathrm{g} \mathrm{m}^{2} \mathrm{~min}^{-1}\right)$; and sulfides including DMDS $\left(0.870 \mu \mathrm{g} \mathrm{m}^{2} \mathrm{~min}^{-1}\right)$ and DMTS $\left(0.187 \mu \mathrm{g} \mathrm{m}^{2} \mathrm{~min}^{-1}\right)$.

In the present study, manure obtained from cattle diets containing $0 \%, 10 \%$, or $30 \%$ WDGS was also applied to meet the one-year $\mathrm{N}$ requirement for corn. However, water was applied continuously for $24 \mathrm{~h}$ immediately following manure application on day 1. Principal odorous VOC emissions (saturated condition, table 5 of this study) were VFA including heptanoic acid $\left(0.038 \mu \mathrm{g} \mathrm{m}^{2} \mathrm{~min}^{-1}\right)$, hexanoic acid $\left(0.289 \mu \mathrm{g} \mathrm{m}^{2} \mathrm{~min}^{-1}\right)$, isobutyric acid $\left(0.038 \mu \mathrm{g} \mathrm{m}^{2} \mathrm{~min}^{-1}\right)$, and isovaleric acid $\left(0.016 \mu \mathrm{g} \mathrm{m}^{2} \mathrm{~min}^{-1}\right)$; aromatics including indole $\left(0.008 \mu \mathrm{g} \mathrm{m}^{2} \mathrm{~min}^{-1}\right)$ and skatole $\left(0.0005 \mu \mathrm{g} \mathrm{m}^{2} \mathrm{~min}^{-1}\right)$; and sulfides including DMDS $\left(0.219 \mu \mathrm{g} \mathrm{m}^{2} \mathrm{~min}^{-1}\right)$ and DMTS $\left(0.050 \mu \mathrm{g} \mathrm{m}^{2} \mathrm{~min}^{-1}\right)$.

A $24 \mathrm{~h}$ period of rainfall following manure application (day 1 , table 5 of this study) produced substantially different types and amounts of VOC emissions than a single rainfall event occurring $24 \mathrm{~h}$ after land application (day 2, table 5 of Woodbury et al., 2014). For the principal VOC that were the same in both studies, the emissions reported by Woodbury et al. (2014) were greater. Greater concentrations of VOC constituents may have been present at the time of application in the manure collected by Woodbury et al. (2014). Emissions of VOC constituents in both studies were greater with surface application than with incorporated manure, except for heptanoic acid. With the exception of sulfides, which can be produced under anaerobic conditions, emissions of VOC were greater during the first $24 \mathrm{~h}$ after manure application.

Woodbury et al. (2015) conducted a laboratory study to evaluate the effects of pen location, soil water content, and temperature on VOC emissions from surface materials obtained from feedlot pens where cattle were fed a diet containing 30\% WDGS. Surface materials were collected from the bunk, mound, and drainage areas of the pens, mixed with water to represent dry, wet, or saturated conditions, and then 
incubated at temperatures of $5^{\circ} \mathrm{C}, 15^{\circ} \mathrm{C}, 25^{\circ} \mathrm{C}$, and $35^{\circ} \mathrm{C}$. Mean odorous VOC emissions measured by Woodbury et al. (2015) and those reported in the present study (shown in parentheses) were: VFA including heptanoic acid 0.042 (0.034) $\mu \mathrm{g} \mathrm{m}^{-2} \mathrm{~min}^{-1}$ and hexanoic acid $0.334(0.258) \mu \mathrm{g} \mathrm{m}^{-2}$ $\mathrm{min}^{-1}$; aromatics including indole $0.003(0.005) \mu \mathrm{g} \mathrm{m}^{-2} \mathrm{~min}^{-1}$ and skatole $0.0006(0.0004) \mu \mathrm{g} \mathrm{m}^{-2} \mathrm{~min}^{-1}$; and sulfides including DMDS $2.29(0.135) \mu \mathrm{g} \mathrm{m}^{-2} \mathrm{~min}^{-1}$ and DMTS 0.170 (0.030) $\mu \mathrm{g} \mathrm{m}^{-2} \mathrm{~min}^{-1}$. Except for indole, the mean emissions measured by Woodbury et al. (2015) were greater than values obtained in this study. The larger VOC emissions reported by Woodbury et al. (2015) are attributed to greater amounts of VOC in the manure, which was derived from a single diet containing 30\% WDGS.

Woodbury et al. (2016) also measured VOC emissions after land application of manure from cattle fed a diet of $30 \%$ WDGS. Manure was either surface-applied or incorporated at rates required to meet the $0.5,1$, or 2 year $\mathrm{N}$ requirements for corn. Approximately $24 \mathrm{~h}$ after manure application, a single application of water was added to the experimental sites until runoff occurred. Mean odorous VOC emissions measured by Woodbury et al. (2016) and those reported in the present study (shown in parentheses) were: VFA including hexanoic acid $0.369(0.258) \mu \mathrm{g} \mathrm{m}^{-2} \mathrm{~min}^{-1}$ and isovaleric acid $0.028(0.014) \mu \mathrm{g} \mathrm{m}^{-2} \mathrm{~min}^{-1}$; aromatics including indole 0.003 (0.005) $\mu \mathrm{g} \mathrm{m}^{-2} \mathrm{~min}^{-1}$; and sulfides including DMDS 0.412 (0.135) $\mu \mathrm{g} \mathrm{m}^{-2} \mathrm{~min}^{-1}$ and DMTS 0.067 (0.030) $\mu \mathrm{g} \mathrm{m}^{-2} \mathrm{~min}^{-1}$. If the VOC concentrations before manure application, climate factors, and other variables are assumed to be similar, the larger VOC emissions measured by Woodbury et al. (2016) are thought to be influenced by the greater manure application rates.

\section{CONCLUSIONS}

VOC emitted following land application of beef cattle manure may be a potential concern. VFA with notable contributions to total OAV included heptanoic, hexanoic, isobutyric, and isovaleric acids, with values of $23.5 \%, 17.6 \%$, $9.26 \%$, and $3.39 \%\left(0.034,0.258,0.030\right.$, and $0.014 \mu \mathrm{g} \mathrm{m}^{-2}$ $\left.\min ^{-1}\right)$, respectively. The two aromatics that contributed substantially to total OAV were indole and skatole, with values of $14.7 \%$ and $8.84 \%\left(0.005\right.$, and $\left.0.0004 \mu \mathrm{g} \mathrm{m}^{-2} \mathrm{~min}^{-1}\right)$, respectively. The sulfides (DMDS and DMTS) contributed $9.50 \%$ and $5.68 \%\left(0.013\right.$ and $\left.0.030 \mu \mathrm{g} \mathrm{m}^{-2} \mathrm{~min}^{-1}\right)$, respectively, to total OAV.

Incorporation of manure following land application reduced the flux values of each of the important VOC odor contributors, except heptanoic acid. The DMDS and DMTS emissions of 0.328 and $0.074 \mu \mathrm{g} \mathrm{m}^{-2} \mathrm{~min}^{-1}$, respectively, for the $30 \%$ WDGS diet were substantially greater than the emissions measured for the $0 \%$ and $10 \%$ WDGS diets. Flux values were greater on the first day following land application (saturated soil water condition) than on the second day (wet soil water condition). For example, the skatole emission of $0.0005 \mu \mathrm{g} \mathrm{m}^{-2} \mathrm{~min}^{-1}$ measured for under saturated soil water conditions was significantly greater than the emission of $0.0002 \mu \mathrm{g} \mathrm{m}^{-2} \mathrm{~min}^{-1}$ measured under wet conditions.
From this study and the results reported by Woodbury et al. (2014), VOC emissions may be influenced by diet, application method, soil water content, and time since manure application. An effective best management practice for reducing VOC emissions is to incorporate beef cattle manure soon after application. If sulfide compounds are expected to be substantial contributors to OAV, then diets containing $30 \%$ WDGS or greater should be avoided.

The emission rates for the largest contributors to OAV occurred under saturated soil water conditions. The frequency and duration of precipitation events on land application sites cannot be controlled. However, delaying land application when there is a high probability of rainfall would reduce the potential of large VOC emissions. In this study, VOC emissions decreased substantially by the end of the test period. Therefore, off-site transport of VOC can be reduced if manure application occurs on days when wind speeds soon after manure application are minimal. Potential odor concerns may be diminished by employing a combination of best manure management and land application practices.

\section{REFERENCES}

Andersen, K. B., Hansen, M. J., \& Feilberg, A. (2012). Minimisation of artefact formation of dimethyl disulphide during sampling and analysis of methanethiol in air using solid sorbent materials. J. Chromatogr. A, 1245, 24-31. https://doi.org/10.1016/j.chroma.2012.05.020

Auvermann, B. W., Paila, A. N., Hiranuma, N., \& Bush, J. (2007). Open-path transmissometry to determine atmospheric extinction efficiency associated with feedyard dust. Proc. Intl. Symp. on Air Quality and Waste Management for Agriculture. St. Joseph, MI: ASABE. https://doi.org/10.13031/2013.23851

DiSpirito, A. A., Zahn, J. A., Russell, D. W., Cooper, E. E., \& Hatfield, J. L. (1994). Development of a standardized method for odor quantification from livestock wastes: Development of a odor index. NPB No. 97-1994. Des Moines, IA: National Pork Board. Retrieved from https://porkcheckoff.org/wpcontent/uploads/2021/02/97-1994-DISPIRITO-ISU.pdf

Donham, K. J., Wing, S., Osterberg, D., Flora, J. L., Hodne, C., Thu, K. M., \& Thorne, P. S. (2007). Community health and socioeconomic issues surrounding concentrated animal feeding operations. Environ. Health Perspect., 115(2), 317-320. https://doi.org/10.1289/ehp.8836

Edmeades, D. C. (2003). The long-term effects of manures and fertilisers on soil productivity and quality: A review. Nutr. Cycling Agroecosyst., 66(2), 165-180. https://doi.org/10.1023/A:1023999816690

Eghball, B., Wienhold, B. J., Gilley, J. E., \& Eigenberg, R. A. (2002). Mineralization of manure nutrients. J. Soil Water Cons., 57(6), 470-478.

Fauci, M. F., \& Dick, R. P. (1994). Soil microbial dynamics: Shortand long-term effects of inorganic and organic nitrogen. SSSA J., 58(3), 801-806. https://doi.org/10.2136/sssaj1994.03615995005800030023x

Ferguson, R. B., Nienaber, J. A., Eigenberg, R. A., \& Woodbury, B. L. (2005). Long-term effects of sustained beef feedlot manure application on soil nutrients, corn silage yield, and nutrient uptake. J. Environ. Qual., 34(5), 1672-1681. https://doi.org/10.2134/jeq2004.0363

Friedrich, J. E., \& Acree, T. E. (1998). Gas chromatography olfactometry (GC/O) of dairy products. Intl. Dairy J., 8(3), 235241. https://doi.org/10.1016/S0958-6946(98)80002-2 
Gralapp, A. K., Powers, W. J., Faust, M. A., \& Bundy, D. S. (2002). Effects of dietary ingredients on manure characteristics and odorous emissions from swine. J. Animal Sci., 80(6), 1512-1519. https://doi.org/10.2527/2002.8061512x

Hales, K. E., Parker, D. B., \& Cole, N. A. (2012). Potential odorous volatile organic compound emissions from feces and urine from cattle fed corn-based diets with wet distillers grains and solubles. Atmos. Environ., 60, 292-297.

https://doi.org/10.1016/j.atmosenv.2012.06.080

Hales, K., Parker, D. B., \& Cole, N. A. (2015). Volatile organic compound flux from manure of cattle fed diets differing in grain processing method and co-product inclusion. Atmos. Environ., 100, 20-24. https://doi.org/10.1016/j.atmosenv.2014.10.037

Hanna, H. M., Bundy, D. S., Lorimor, J. C., Mickelson, S. K., Melvin, S. W., \& Erbach, D. C. (2000). Manure incorporation equipment effects on odor, residue cover, and crop yield. Appl. Eng. Agric., 16(6), 621-627. https://doi.org/10.13031/2013.5376

Heederik, D., Sigsgaard, T., Thorne, P. S., Kline, J. N., Avery, R., Bonlokke, J. H., ... Merchant, J. A. (2007). Health effects of airborne exposures from concentrated animal feeding operations. Environ. Health Perspect., 115(2), 298-302. https://doi.org/10.1289/ehp.8835

Katja, R., Schulze, A., Ehrenstein, V., van Strien, R. T., Praml, G., \& Nowak, D. (2007). Environmental exposure to confined animal feeding operations and respiratory health of neighboring residents. Epidemiology, 18(3), 300-308.

Koelsch, R. K., Woodbury, B. L., Stenberg, D. E., Miller, D. N., \& Schulte, D. D. (2004). Total reduced sulfur concentrations in the vicinity of beef cattle feedlots. Appl. Eng. Agric., 20(1), 77-85. https://doi.org/10.13031/2013.15684

Kyoung, S. D., Hunt, P. G., Johnson, M. H., Szogi, A. A., \& Vanotti, M. B. (2007). Path integrated optical remote sensing technique to estimate ammonia and methane emissions from CAFOs. Proc. Intl. Symp. on Air Quality and Waste Management for Agriculture. St. Joseph, MI: ASABE. https://doi.org/10.13031/2013.23855

Lau, A., Bittman, S., \& Lemus, G. (2003). Odor measurements for manure spreading using a subsurface deposition applicator. $J$. Environ. Sci. Health B, 38(2), 233-240. https://doi.org/10.1081/PFC-120018452

Liu, D., Nyord, T., Rong, L., \& Feilberg, A. (2018). Real-time quantification of emissions of volatile organic compounds from land spreading of pig slurry measured by PTR-MS and wind tunnels. Sci. Total Environ., 639, 1079-1087. https://doi.org/10.1016/j.scitotenv.2018.05.149

Mackie, R. I., Stroot, P. G., \& Varel, V. H. (1998). Biochemical identification and biological origin of key odor components in livestock waste. J. Animal Sci., 76(5), 1331-1342. https://doi.org/10.2527/1998.7651331x

McGinn, S. M., Janzen, H. H., \& Coates, T. (2003). Atmospheric ammonia, volatile fatty acids, and other odorants near beef feedlots. J. Environ. Qual., 32(4), 1173-1182. https://doi.org/10.2134/jeq2003.1173

Miller, D. N., \& Berry, E. D. (2005). Cattle feedlot soil moisture and manure content: I. Impacts on greenhouse gases, odor compounds, nitrogen losses, and dust. J. Environ. Qual., 34(2), 644-655. https://doi.org/10.2134/jeq2005.0644

Miller, D. N., \& Varel, V. H. (2001). In vitro study of the biochemical origin and production limits of odorous compounds in cattle feedlots. J. Animal Sci., 79(12), 2949-2956. https://doi.org/10.2527/2001.79122949x

Mitloehner, F. M., \& Calvo, M. S. (2008). Worker health and safety in concentrated animal feeding operations. J. Agric. Saf. Health, 14(2), 163-187. https://doi.org/10.13031/2013.24349

Parker, D. B., Gilley, J., Woodbury, B., Kim, K.-H., Galvin, G., Bartelt-Hunt, S. L., ... Snow, D. D. (2013a). Odorous VOC emission following land application of swine manure slurry. Atmos. Environ., 66, 91-100.

https://doi.org/10.1016/j.atmosenv.2012.01.001

Parker, D. B., Perschbacher-Buser, Z. L., Cole, N. A., \& Koziel, J. A. (2010). Recovery of agricultural odors and odorous compounds from polyvinyl fluoride film bags. Sensors, 10(9), 8536-8552. https://doi.org/10.3390/s100908536

Parker, D., Ham, J., Woodbury, B., Cai, L., Spiehs, M., Rhoades, M., ... Cole, A. (2013b). Standardization of flux chamber and wind tunnel flux measurements for quantifying volatile organic compound and ammonia emissions from area sources at animal feeding operations. Atmos. Environ., 66, 72-83. https://doi.org/10.1016/j.atmosenv.2012.03.068

Patton, S., \& Josephson, D. V. (1957). A method for determining significance of volatile flavor compounds in foods. J. Food Sci., 22(3), 316-318. https://doi.org/10.1111/j.13652621.1957.tb17017.x

Powers, W. J. (2001). Development of procedures for odor evaluation techniques. Proc. 1st IWA Intl. Conf. on Odour and VOCs: Measurement, Regulation, and Control Techniques. Sydney, NSW, Australia: University of New South Wales.

Rappert, S., \& Muller, R. (2005). Odor compounds in waste gas emissions from agricultural operations and food industries. Waste Mgmt., 25(9), 887-907. https://doi.org/10.1016/j.wasman.2005.07.008

SAS. (2011). SAS/STAT User's Guide. Vers. 9.3. Vol. 1. 4th ed. Cary, NC: SAS Institute.

Spiehs, M. J., \& Varel, V. H. (2009). Nutrient excretion and odorant production in manure from cattle fed corn wet distillers grains with solubles. J. Animal Sci., 87(9), 2977-2984. https://doi.org/10.2527/jas.2008-1584

Spiehs, M. J., Jaderborg, J. P., Hales, K. E., DiCostanzo, A., Crawford, G. I., \& Parker, D. B. (2018). Effect of corn processing and wet distiller's grains with solubles on odorous volatile organic compound emissions from urine and feces of beef cattle. Appl. Eng. Agric., 34(3), 591-598. https://doi.org/10.13031/aea.12708

Spiehs, M. J., Miller, D. N., Woodbury, B. L., Eigenberg, R. A., Varel, V. H., \& Parker, D. B. (2012). Effect of feeding wet distillers grains with solubles to beef cattle on air and manure quality. Appl. Eng. Agric., 28(3), 423-430. https://doi.org/10.13031/2013.41491

Tester, C. F. (1990). Organic amendment effects on physical and chemical properties of a sandy soil. SSSA J., 54(3), 827-831. https://doi.org/10.2136/sssaj 1990.03615995005400030035x

Thorne, P. S. (2007). Environmental health impacts of concentrated animal feeding operations: Anticipating hazards - Searching for solutions. Environ. Health Perspect., 115(2), 296-297. https://doi.org/10.1289/ehp.8831

Todd, R. W., Cole, N. A., Clark, R. N., Flesch, T. K., Harper, L. A., \& Baek, B. H. (2008). Ammonia emissions from a beef cattle feedyard on the southern High Plains. Atmos. Environ., 42(28), 6797-6805. https://doi.org/10.1016/j.atmosenv.2008.05.013

Trabue, S. L., Anhalt, J. C., \& Zahn, J. A. (2006). Bias of Tedlar bags in the measurement of agricultural odorants. J. Environ. Qual., 35(5), 1668-1677. https://doi.org/10.2134/jeq2005.0370

Trabue, S. L., Scoggin, K. D., Li, H., Burns, R., \& Xin, H. (2008). Field sampling method for quantifying odorants in humid environments. Environ. Sci. Tech., 42(10), 3745-3750. https://doi.org/10.1021/es7031407

Trabue, S., Scoggin, K., McConnell, L., Maghirang, R., Razote, E., \& Hatfield, J. (2011). Identifying and tracking key odorants from cattle feedlots. Atmos. Environ., 45(25), 4243-4251. https://doi.org/10.1016/j.atmosenv.2011.04.081

Varel, V. H., Wells, J. E., Berry, E. D., \& Miller, D. N. (2010). Manure odor potential and Escherichia coli concentrations in 
manure slurries of feedlot steers fed $40 \%$ corn wet distillers grains. J. Environ. Qual., 39(4), 1498-1506. https://doi.org/10.2134/jeq2009.0472

Varel, V. H., Wells, J. E., Berry, E. D., Spiehs, M. J., Miller, D. N., Ferrell, C. L., ... Koohmaraie, M. (2008). Odorant production and persistence of Escherichia coli in manure slurries from cattle fed zero, twenty, forty, or sixty percent wet distillers grains with solubles. J. Animal Sci., 86(12), 3617-3627. https://doi.org/10.2527/jas.2008-1118

Woodbury, B. L., Gilley, J. E., Parker, D. B., \& Stromer, B. S. (2018). Greenhouse gas emissions from beef feedlot surface materials as affected by diet, moisture, temperature, and time. Trans. ASABE, 61(2), 571-582. https://doi.org/10.13031/trans.12483

Woodbury, B. L., Gilley, J. E., Parker, D. B., Marx, D. B., \& Eigenberg, R. A. (2015). VOC emissions from beef feedlot pen surfaces as affected by within-pen location, moisture, and temperature. Biosyst. Eng., 134, 31-41. https://doi.org/10.1016/j.biosystemseng.2015.03.014

Woodbury, B. L., Gilley, J. E., Parker, D. B., Marx, D. B., \& Eigenberg, R. A. (2016). Emission of volatile organic compounds as affected by rate of application of cattle manure. Trans. ASABE, 59(3), 885-895. https://doi.org/10.13031/trans.59.11374

Woodbury, B. L., Gilley, J. E., Parker, D. B., Marx, D. B., Miller, D. N., \& Eigenberg, R. A. (2014). Emission of volatile organic compounds after land application of cattle manure. J. Environ. Qual., 43(4), 1207-1218.

Wright, D. W., Eaton, D. K., Nielsen, L. T., Kuhrt, F. W., Koziel, J. A., Spinhirne, J. P., \& Parker, D. B. (2005). Multidimensional gas chromatography-olfactometry for the identification and prioritization of malodors from confined animal feeding operations. J. Agric. Food. Chem., 53(22), 8663-8672. https://doi.org/10.1021/jf050763b

Zahn, J. A., DiSpirito, A. A., Do, Y. S., Brooks, B. E., Cooper, E. E., \& Hatfield, J. L. (2001). Correlation of human olfactory responses to airborne concentrations of malodorous volatile organic compounds emitted from swine effluent. J. Environ. Qual., 30, 624-634.

\section{NOMENCLATURE}

$\mathrm{AFO}=$ animal feeding operation

DMDS $=$ dimethyl disulfide

DMTS $=$ dimethyl trisulfide

$\mathrm{OAV}=$ odor activity value

SCOT $=$ single-compound odor threshold

$\mathrm{VFA}=$ volatile fatty acid

$\mathrm{VOC}=$ volatile organic compounds

$\mathrm{VSC}=$ volatile sulfur compounds

WDGS $=$ wet distillers grains with solubles 